\title{
First Record of Coral Red Khukri Snake (Oligodon kheriensis) from Uttarakhand, India: Expanding the Current Known Dispersal Range of the Species
}

\author{
Vipul Maurya ${ }^{1}$, Jai Pratap Singh ${ }^{2}$, Parag M. Dhakate ${ }^{3}$ \\ ${ }^{1}$ School of Forestry and Environment, Sam Higginbottom Institute of Agriculture, Technology and Sciences, Allahabad, Uttar Pradesh, \\ 211007, India \\ ${ }^{2}$ Resham Majri Village, Dehradun, Uttarakhand, 248140, India \\ ${ }^{3}$ Conservator of Forest, Western Circle, Haldwani, Uttarakhand, 263139, India
}

\begin{abstract}
We reported the new record of Coral Red Khukri Snake (Oligodon kheriensis) from Surai Range of Haldwani -Tarai East Forest Division, Uttarakhand. The specimen of Oligodon kheriensis had been spotted only four times in the past. This is the first report of this Snake from Uttarakhand. We encountered 6 different individuals of Oligodon kheriensis over a period of ten months.
\end{abstract}

Keywords: New Record, Oligodon kheriensis, Distribution, Tarai East Forest Division, Uttarakhand

\section{Introduction}

The herpetofauna (reptiles and amphibians) of India is represented by 518 species of reptiles and 314 species of amphibians (Angals et al. 2011, Dinesh et al. 2011). Unfortunately, snakes have received less ecological study than other reptiles, and the studies that do exist may be under represented in the literature (Seigel 1993, Bonnet et al. 2002).However, many snake species are often recorded only by a single or rather few specimens, and data on their distribution and natural history are still deficient. The most recent sighting of Coral Red Khukri Snake (Oligodon kheriensis) which was discovered by Acharji and Ray in 1936 was belong to Genus Oligodon. The genus Oligodon Fitzinger 1826, is widely distributed in South East Asia which contains 70 species that preys on small rodents, tadpoles, frogs and insects (Batchelor, 1958; Cox, 1991; David and Vogel, 1996; Hu, 2001; Hwang et al.1965). We here in provide an updated distribution location from Tarai East Forest Division of Uttarakhand and improve our understanding of this species in this region.

\section{Study Area}

Surai Forest Range is a part of Tarai East Forest Division, Haldwani in Uttarakhand, covering a total area of 15712.50 hectares. It is mainly Sal forest interspersed with teak and eucalyptus plantations and open grasslands. It is bound by forests of the Khatima range to the north, Pilibhit Tiger Reserve to the East and South, and human habitations of Khatima sub-division (Udham Singh Nagar District) to the West. The forest is criss-crossed by numerous waterways, mainly irrigation canals, which provide a drinking source for the fauna and also recharge the ground water table.

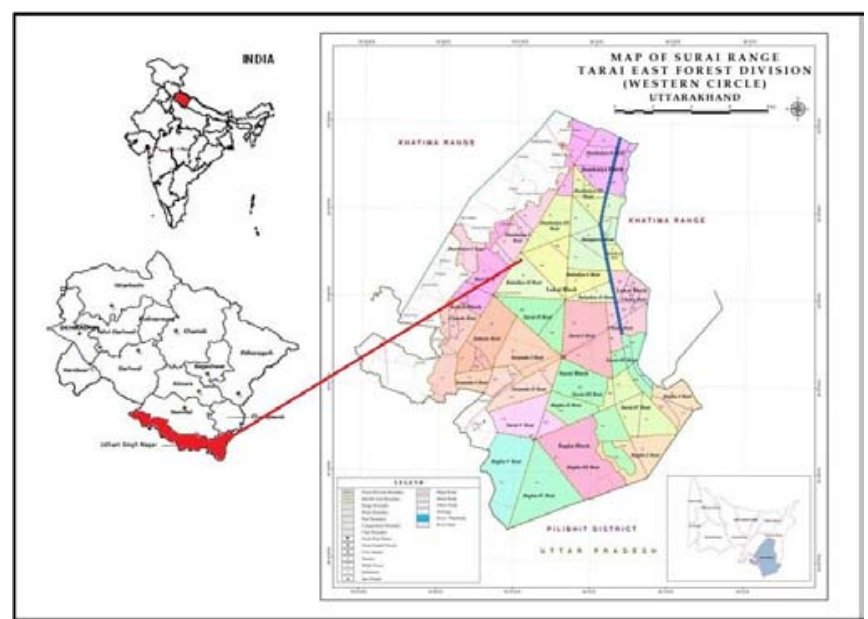

Figure: Map of the Study Area

\section{Methodology}

A Field Survey for documenting Herpetofauna in Tarai East Forest Division of Uttarakhand was conducted from September 2014 to July 2015.The entire area was divided into small zones. Each zone was randomly (biased) explored on the basis of habitat structure and, possibility and availability of the species. All important major and minor water bodies, including seasonal rivulets were extensively explored for species. For collection of as many species as possible, a wide range of sampling methods were adopted viz., active searching and refuge examination of aquatic vegetation, paddy fields, bushes, waterfalls, bamboo bushes, along road sides, canals, streams, underneath of stones, logs, barks, tree holes, banks of ponds, lakes, rivers and leaf litter etc. Encountered snakes were photographed in the field and species identification is only based on the photographs. Morning surveys were conducted along the water bodies, mainly canals and on the forest roads. Ponds and marshy habitats were surveyed during the day as well as night. Night surveys during winters were conducted along the roads as they are favourable hot spots for both reptilian and amphibian species during cold seasons. 


\section{International Journal of Science and Research (IJSR) \\ ISSN (Online): 2319-7064}

Index Copernicus Value (2015): 78.96 | Impact Factor (2015): 6.391

\section{Result and Discussion}

During field surveys for documenting the herpetofaunal diversity of the Tarai East Forest Division, Uttarakhand, we encountered 6 different individuals of Coral Red Khukri Snake (Oligodon kheriensis) over a period of ten months (September 2014 to July 2015). Out of these six specimens, four were captured live and two were found dead due to road kill. The live specimens were released at the same spots after recording their scale counts and measurements and taking photographs.

Identification was confirmed by referring to the description of the species provided in the (Acharji and Ray 1936, Schleich H. H. and Kästle W 2002, Sutradhar, S., Anukul.N 2013, Sangma, M.A., P.k. Saikia, 2014) papers. All Specimens were found near water bodies with vegetation Bahera (Terminalia bellerica), Kamlai (Lannea grandis), Patala (Stereospermum chelonoides, Kadam (Haldina cordifolia), Grader Grass (Themeda caudate), Munja Grass
(Saccharum munja), Kans Grass(Saccharum spontaneum) etc.

\section{Description}

This is rare Species and reported only four times from Uttar Pradesh (Acharji and Ray 1936), Nepal (Schleich H. H. and Kästle W 2002), Assam (Sutradhar, S., Anukul.N 2013) and Meghalaya (Sangma, M.A., P.k. Saikia, 2014). Length of the specimens of Coral Red Khukri Snake varied from 48 to 114 cms. Dorsal colour in all snakes was uniformly coral red / bright orange. Ventral coloration varied from white to pale yellow to light pink. Ventral scales were uniformly 187 in number in all specimens, with 42 paired subcaudals and an entire anal vent. Dorsal scales were smooth and arranged in 19:19:17 rows. Pupil of eye was round. This study indicates Coral Red Khukri Snake range expansion over the past reported locations.

\section{Dates and Location Details of Specimens are Provided in the Following Table:}

Table 1: Details of Coral Red Khukri Snake (Oligodon kheriensis) from Terai East Forest Division, Uttarakhand

\begin{tabular}{|c|c|c|c|c|c|c|c|c|}
\hline Specimen & Latitude & Longitude & Altitude (meters) & Status & Length (cm) & Dorsal Scale Count & Ventrals & Subcaudals \\
\hline 1 & $28^{\circ} 48^{\prime} 10.25^{\prime \prime} \mathrm{N}$ & $80^{\circ} 01^{\prime} 11.19^{\prime \prime} \mathrm{E}$ & 207 & Dead & 114 & $19: 19: 17$ & 187 & 42 \\
\hline 2 & $28^{\circ} 52^{\prime} 33.26^{\prime \prime} \mathrm{N}$ & $80^{\circ} 01^{\prime} 21.68^{\prime \prime} \mathrm{E}$ & 195 & Live & 97 & $19: 19: 17$ & 187 & 42 \\
\hline 3 & $28^{\circ} 51^{\prime} 39.67^{\prime \prime} \mathrm{N}$ & $80^{\circ} 00^{\prime} 17.19^{\prime \prime} \mathrm{E}$ & 224 & Live & 105 & $19: 19: 17$ & 187 & 42 \\
\hline 4 & $28^{\circ} 58^{\prime} 21.92^{\prime \prime} \mathrm{N}$ & $80^{\circ} 02^{\prime} 23.58^{\prime \prime} \mathrm{E}$ & 225 & Dead & 79 & $19: 19: 17$ & 187 & 42 \\
\hline 5 & $28^{\circ} 48^{\prime} 40.27^{\prime \prime} \mathrm{N}$ & $79^{\circ} 59^{\prime} 34.50^{\prime \prime} \mathrm{E}$ & 208 & Live & 48 & $19: 19: 17$ & 187 & 42 \\
\hline 6 & $28^{\circ} 47^{\prime} 05.70^{\prime \prime} \mathrm{N}$ & $80^{\circ} 03^{\prime} 15.36^{\prime \prime} \mathrm{E}$ & 217 & Live & 107 & $19: 19: 17$ & 187 & 42 \\
\hline
\end{tabular}

\section{Acknowledgement}

The authors are thankful to the Uttarakhand Forest Department. Thanks are also due to field staff of Surai and Khatima Range of Tarai East Forest Division, Haldwani for their co-operation and help throughout the field work.

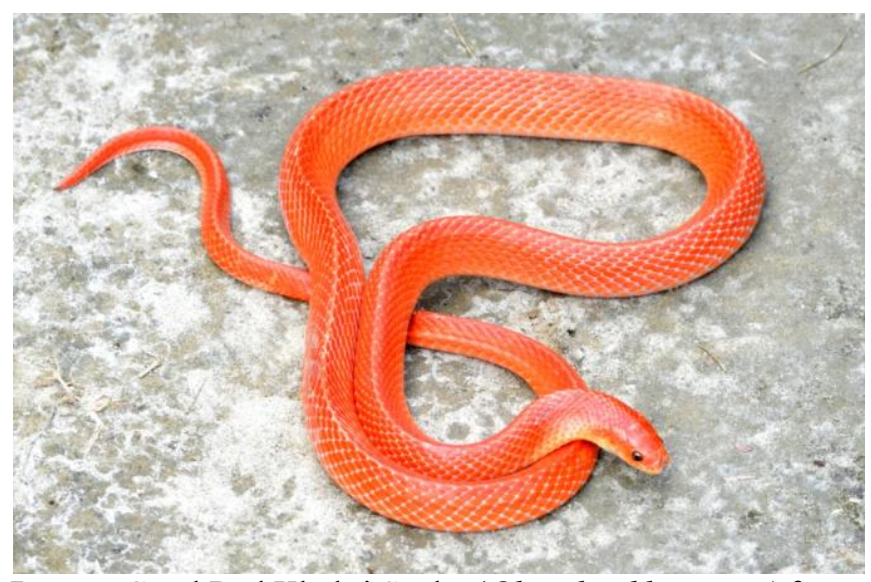

Image: Coral Red Khukri Snake (Oligodon kheriensis) from road side

(Photo courtesy: Vipul Maurya)

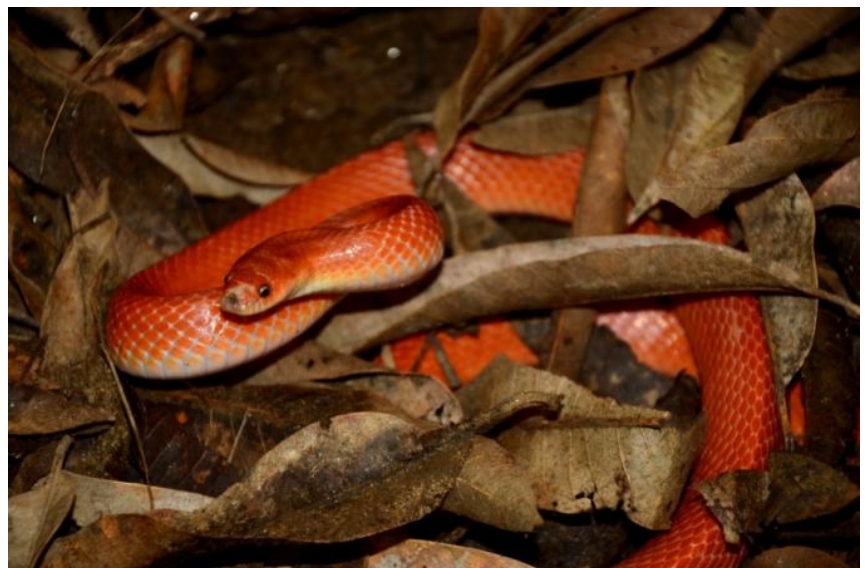

Image: Coral Red Khukri Snake (Oligodon kheriensis) (Photo courtesy: Vipul Maurya)

\section{References}

[1] Acharji M. N. and Ray H. C. 1936, «A new species of Oligodon from the United Provinces (India), Rec. Ind. Mus., 38, $519-520$.

[2] Aengals R, Sathish Kumar VM, Palot MJ 2011. Updated Checklist of Indian Reptiles. Zoological Survey of India. zsi.gov.in/ checklist/ Reptiles.

[3] Batchelor, D. M., 1958. Some notes on the snakes of Asahan, Malacca. Malayan Nature Journal. 12, 103111. 


\section{International Journal of Science and Research (IJSR) \\ ISSN (Online): 2319-7064}

Index Copernicus Value (2015): 78.96 | Impact Factor (2015): 6.391

[4] Bonnet, X., R. Shine, and O. Lourdais. 2002. Taxonomic chauvinism. Trends in Ecology and Evolution 17:1-3.

[5] Cox, M. J., 1991. The Snakes of Thailand and Their Husbandry. Robert E. Krieger, Malabar (Florida).

[6] David, P., Vogel, G., 1996. The Snakes of Sumatra: An Annotated Checklist and Key With Natural History Notes. Edition Chimaira, Frankfurt am Main.

[7] Dinesh KP, Radhakrishnan C, Gururaja KV, Deuti K, Bhatta G 2011. A Checklist of Amphibia of India. Zoological Survey of India. zsi.gov.in/checklist/Amphibia.

[8] Fitzinger, L. J., 1826. Neue Classification der Reptilien nach ihren Natürlichen Verwandtschaften. J. G. Heubner, Vienna.

[9] $\mathrm{Hu}, \mathrm{C} . \mathrm{H} ., 2001$. Endangered species in a biodiverse web: Conservation of Green Sea Turtle impacts native egg-eating snake In Society for Conservation Biology, Hilo, Hawaii.

[10]Hwang, M.-h., Ho, S.-s., Chou, S.-a., Hsieh, T.-t., Hu, B.-c., 1965. Feeding habits of snakes from Chekiang [=Zhejiang]. Acta Zoologica Sinica. 17, 137-146.

[11] Seigel, R. A. 1993. Summary: future research on snakes, or how to combat "lizard envy." Pages 395402 in R. A. Seigel and J. T. Collins, editors. Snakes: ecology and behavior. McGraw-Hill, New York, New York, USA.

[12] Schleich H. H. and Kästle W. 2002, Amphibians and Reptiles of Nepal, A. R. G. Gantner Verlag KG

[13] Sutradhar, S., Anukul.N.2013, An account on poorly known corral red snake oligodon kheriensis acharji et ray, 1936 from assam, india. Russian Journal of Herpetology, Vol.20, No.4, pp.247-252.

[14] Sangma, M.A., P.k. Saikia 2014, New record of Snakes in Tura Peak of West Garo Hills, Meghalaya, India. Journal on New Biological Reports 3 (3): 262-270 